\title{
PENERAPAN METODE KISAH DALAM PENINGKATAN PENGAMALAN SHALAT ANAK PADA ORANGTUA TUNGGAL DI DESA MANEGEN KECAMATAN PADANGSIDIMPUAN TENGGARA Oleh: Zubaidah dan Magdalena
}

\begin{abstract}
ABSTRAK
Dalam pendidikan Islam orangtua mempunyai peranan yang sangat penting dalam membina anaknya yaitu sebagai pendidik dan pembimbing dalam melaksanakan ajaran-ajaran Islam. Salah satu hal yang sangat penting untuk ditanamkan dalam kebiasaan anak adalah pengamalan ibadah Shalat. Skripsi ini membahas penerapan metode kisah dalam peningkatan pengamalan Shalat anak pada orangtua tunggal di Desa Manegen Kecamatan Padangsidimpuan Tenggara.

Metode kisah merupakan cara yang dilakukan untuk menyampaikan materi atau pelajaran melalui cerita kepada anak didik. Metode yang dilakukan dengan bercerita adalah mengungkapkan peristiwa yang mengandung nilai pendidikan moral, rohani dan sosial untuk anak didik baik cerita yang bersifat kebaikan, maupun kezaliman, atau juga ketimpangan jasmani-rohani, material-spritual yang dapat melumpuhkan semangat manusia.

Penelitian ini dibahas melalui studi lapangn dengan penelitian riset aksi partisipatori yang terdiri dari tiga siklus, yaitu siklus I, siklus II dan siklus III. Dimana setiap siklus terdiri dari 4 tahapan, yaitu perencanaan, tindakan, observasi dan refleksi. Subjek penelitian ini adalah anak-anak usia 6-12 tahun dalam keluarga orangtua tunggal yang berjumlah 6 orang anak. Data penelitian diperoleh dari hasil observasi mendengarkan kisah dan observasi membaca kisah serta dokumentasi berupa catatan pengamalan Shalat anak yang disajikan dalam bentuk data kualitatif.

Dari penelitian yang dilaksanakan diperoleh hasil bahwa pengamalan Shalat anak mengalami peningkatan meskipun pengamalan Shalat perminggu perkelompok masih jauh dari jumlah ideal. Jumlah pengamalan Shalat anak yang ideal perminggu dan perorang adalah 35. Sedangkan jumlah ideal pengamalan Shalat anak perminggu perkelompok adalah 210.

Kata Kunci : Metode Kisah dan Pengalaman Shalat
\end{abstract}

\begin{abstract}
In Islamic education parents have a very important role in fostering their children, namely as educators and mentors in implementing Islamic teachings. One of the most important things to be instilled in children's habits is the practice of prayer. This thesis discusses the application of the story method in increasing the practice of child prayer in single parents in Manegen Village, Padangsidimpuan Tenggara District.

The story method is a method that is carried out to convey material or lessons through stories to students. The method carried out by telling stories is to reveal events that contain the values of moral, spiritual and social education for students, both good and tyrannical stories, or also physical-spiritual inequality, spiritual material that can paralyze the human spirit.
\end{abstract}


This research was discussed through a field study with participatory action research research consisting of three cycles, namely cycle I, cycle II and cycle III. Where each cycle consists of 4 stages, namely planning, action, observation and reflection. The subjects of this study were children aged 6-12 years in a family of single parents totaling 6 children. The research data was obtained from the results of observing listening to stories and observing reading stories and documentation in the form of observing the children's prayers presented in the form of qualitative data.

From the research carried out the results showed that the practice of children's prayer experienced an increase despite the practice of weekly prayers in groups far from the ideal number. The ideal number of children's prayer practices per week and per person is 35 . While the ideal number of practices for a child's prayer per week is 210 groups.

Keywords: Method of Story and Prayer Experience

\section{A. PENDAHULUAN}

Dalam Islam menuntut ilmu Agama wajib bagi setiap umat baik laki-laki maupun perempuan, karena pendidikan berusaha membentuk pribadi yang berkualitas, baik jasmani maupun rohani. Pendidikan merupakan kebutuhan manusia sepanjang hayat. Setiap manusia membutuhkan pendidikan sampai kapanpun dan dimanapun ia berada. Oleh karena itu, pendidikan memiliki arti penting bagi setiap manusia. Pendidikan dapat membentuk watak anak menjadi pribadi yang berkualitas dan taat beragama.

Dalam pendidikan Islam orangtua mempunyai peranan yang sangat penting dalam membina anaknya yaitu sebagai pendidik dan pembimbing dalam melaksanakan ajaran-ajaran Islam. Oleh karena itu orangtua harus memiliki usaha yang baik dalam membina anak-anaknya. Orangtua harus memberikan perhatian yang cukup kepada anaknya agar anak memiliki kesiapan dalam melaksanakan ajaran Islam.

Sikap keagamaan pada anak harus diasah mulai sejak usia dini agar anak dapat mengamalkan ajaran agama lebih mendalam dan lebih terbiasa melaksanakan ajaran Islam hingga dewasa nanti. Karenanya pendidikan diberikan kepada anak mulai sejak lahir hingga dewasa. Perhatian yang diberikan orangtua kepada anak dapat menghasilkan sebuah prilaku yang positif karena segala tingkah laku anak selalu mendapat arahan dari orangtua. 
Salah satu hal yang sangat penting untuk ditanamkan dalam kebiasaan anak adalah pengamalan ibadah Shalat, karena Shalat merupakan ibadah yang dilakukan rutin dan membutuhkan waktu tersendiri dalam melaksanakannya sehingga perlu adanya pembiasaan terhadap anak supaya anak mempunyai rasa bersalah bila kegiatan tersebut ditinggalkan.

Anak usia 6-12 tahun sangat memerlukan bimbingan dari orangtua, karena anak usia dini belum memahami betul mengenai kegiatan Agama. Orangtua mempunyai tanggung jawab untuk membimbing anak mereka dalam hal ibadah Shalat, supaya anak memiliki kesadaran bahwa Shalat merupakan ibadah yang wajib dilaksanakan. Sebagai umat beragama Islam anak usia dini sudah dikenalkan dengan ibadah Shalat. Jika kemampuan Shalat anak tidak dikembangkan maka akan sulit bagi anak untuk mengulang gerakan Shalat dan enggan melaksanakannya.

Orangtua memerlukan usaha dalam pembinaan pengamalan Shalat anak. Perkembangan agama pada anak memerlukan dorongan dan rangsangan. Minat dan cita-cita anak perlu dikembangkan melalui pembinaan sesuai dengan kemampuannya. Begitu pentingnya peran orangtua dalam mendidik anaknya akan terkendala bilamana orangtua merupakan sosokorangtua tunggal. Dimana ketiadaan salah satu orangtua dalam mendidiknya, tentu hal tersebut menjadi suatu kendala dalam memberikan pendidikan keagamaan pada anak.

Anak yang dibina oleh kedua orangtuanya pasti lebih baik daripada anak yang diasuh oleh ibu atau ayahnya saja. Bila kedua orangtua secara bersama mendidik anaknya tentu ada kerjasama. Tapi jika anak hanya dididik oleh ibu atau ayahnya saja akan terjadi ketidakseimbangan yang akibatnya anak-anak kurang mendapat perhatian dari orangtuanya serta pengasuhan orangtua yang tidak lengkap akan berpengaruh bagi pendidikan anak.

Kisah mempunyai daya tarik yang menyentuh perasaan. Pembaca atau pendengar sebuah cerita tidak dapat tidak bersikap bekerjasama dengan jalan cerita dan orang-orang yang terdapat didalamnya. Sadar atau tidak, ia telah menggiring dirinya untuk mengikuti jalan cerita, mengkhayalkan bahwa ia berada di pihak ini atau itu, dan 
sudah menimbang-nimbang posisinya dengan tokoh cerita, yang mengakibatkan ia senang, benci, atau merasa tidak kagum. ${ }^{1}$

Orangtua menjadi salah satu model pendidikan dalam keluarga. Jika dalam sebuah keluarga tidak terdapat salah satu model orangtua maka anak akan kehilangan sumber pendidikan pada salah satu orangtuanya. Selain itu, menyangkut masalah perekonomian keluarga seorang suami lebih berperan penting dalam masalah material. Seorang suami menjadi tulang punggung keluarga dan seorang istri menjadi ibu rumah tangga biasa.

Berdasarkan observasi pendahuluan yang dilakukan penulis di Desa Manegen menunjukkan bahwa anak melaksanakan Shalat 1 atau 2 kali sehari semalam dan saat tiba waktu Shalat masih ada anak dari orangtua tunggal yang berkeliaran dan bermain. Orangtua kurang begitu tahu apakah anak-anaknya telah mengerjakan Shalat atau belum. Hal ini disebabkan karena orangtua tunggal memiliki kesibukan lebih, dalam memenuhi tuntutan ekonominya, sehingga orangtua kurang perhatian terhadap pentingnya pendidikan agama termasuk pengamalan ibadah Shalat anak. Orangtua hanya sekedar menyuruh saja kurang memberikan dorongan kepada anak sehingga anak kurang termotivasi untuk melaksanakan Shalat.

Berdasarkan fakta dilapangan di Desa Manegen Kecamatan Padangsidimpuan Tenggara masih banyak ditemukan orangtua yang belum membuat variasi metode dalam peningkatan pengamalan Shalat anak. Orangtua hanya menyuruh anak melaksanakan Shalat, tidak memperhatikan apakah anak melaksanakan Shalat atau tidak. Berangkat dari kenyataan tersebut peneliti ingin memfokuskan pada orangtua tunggal. Berdasarkan keadaan itu juga, perlu penanganan serius agar peningkatan pelaksanaan Shalat anak pada orangtua tunggal dapat dicapai. Penerapan metode kisah diharapkan dapat meningkatkan pengamalan Shalat anak melalui pendampingan pada orangtua tunggal.

\footnotetext{
${ }^{1}$ Akbarizan, Pendidikan Berbasis Akhlak, (Pekan Baru: Suska Press), 2008, hlm. 154.
} 


\section{B. KAJIAN TEORI}

\section{Metode Kisah}

Secara etimologi, istilah metode berasal dari bahasa Yunani "metodos". Kata ini terdiri dari dua suku kata: yakni "metha" yang berarti melalui atau melewati dan "hodos" yang berarti jalan atau cara. Metode berarti suatu jalan yang dilakukan untuk mencapai tujuan. Dalam bahasa Arab metode disebut "thariqat", dalam kamus besar Bahasa Indonesia, metode adalah cara yang teratur dan terpikir baik-baik untuk mencapai maksud, sehingga dapat dipahami bahwa metode berarti suatu cara yang harus dilalui untuk menyajikan bahan pelajaran agar tercapai tujuan pengajaran. ${ }^{2}$

Dalam pendidikan, metode adalah cara-cara yang digunakan oleh seorang guru untuk menyampaikan kandungan pelajaran kepada seorang murid untuk mencapai tujuan pendidikan yang terkandung dalam kurikulum.Metode kisah mengandung arti suatu cara dalam menyampaikan materi pelajaran dengan menuturkan secara kronologis tentang bagaimana terjadinya sesuatu hal. ${ }^{3}$

Boleh jadi metode kisah tersebut merupakan suatu faktor pendidikan yang penting untuk menumbuhkan sikap, mengubah nilai-nilai, menyeru kepada kebaikan, serta menghias diri dengan akhlak dan sifat-sifat yang mulia, karena cerita mempunyai daya kekuatan, pengaruh dan bimbingan. Kenyataan menunjukkan bahwa cerita mempunyai pengaruh yang dalam untuk mengadakan perubahan dan pengarahan, sebab khayalan orang yang mendengar cerita maupun yang membacanya akan mengikuti terus kejadian-kejadian dalam cerita itu dan menghayatinya. Ia akan beranjak bersama cerita yang dikisahkan dari satu situasi kesatu dialog, dari satu konsep kesatu perasaan. Dengan demikian bangunlah sentimennya, bergeraklah emosinya. Seolah ia merupakan bagian dari cerita itu, dan kendatipun cerita yang dikisahkan itu telah selesai, tetapi pengaruhnya tetap hidup bersama perasaan para pendengarnya. ${ }^{4}$

\footnotetext{
${ }^{2}$ Armai Arief, Pengantar Ilmu Dan Metodologi Pendidikan Islam, (Jakarta: Ciputat Pers, 2002), hlm. 40 .

${ }^{3}$ Ibid., hlm. 160 .

${ }^{4}$ Muhammad Abdul Qadir Ahmad, Metodologi Pengajaran Agama Islam, (Jakarta: Rineka Cipta, 2008), hlm. 66.
} 
Dengan demikian, metode kisah mempunyai pengaruh yang penting dalam mengadakan perubahan, menumbuhkan nilai-nilai kebaikan dan pengarahan karena orang yang mendengarkan kisah tersebut menghayatinya dan mengikuti jalan cerita sehingga pendengar tertarik dan seolah-olah ia adalah salah satu tokoh dari cerita tersebut.

Metode yang dilakukan dengan bercerita adalah mengungkapkan peristiwa yang mengandung nilai pendidikan moral, rohani dan sosial untuk anak didik baik cerita yang bersifat kebaikan, maupun kezaliman, atau juga ketimpangan jasmani-rohani, material-spritual yang dapat melumpuhkan semangat manusia. Metode cerita ini sangat efektif sekali, terlebih lagi bila sasarannya anak didik yang masih dalam perkembangan "fantastik". Dengan mendengarkan suatu cerita, kepekaan jiwa dan perasaan anak didik dapat tergugah, figur yang baik, membenci yang berbuat jahat (zalim). Cerita itu secara otomatis mendorong anak didik untuk berbuat kebaikan dan dapat membentuk akhlak mulia, serta dapat membina rohani (iman dan takwa). ${ }^{5}$

Dari pengertian di atas dapat disimpulkan bahwa metode kisah merupakan cara yang dilakukan untuk menyampaikan materi atau pelajaran melalui cerita kepada anak didik sehingga dengan cerita tersebut dapat disampaikan pesan-pesan yang baik. Metode kisah dapat digunakan seorang pendidik dalam mendidik peserta didiknya karena kisah yang disampaikan memiliki daya tarik yang dapat menyentuh perasaan pembaca atau pendengar. Kisah termasuk salah satu media pengajaran yang sukses. Ia merupakan satu cara pedidikan yang disenangi anak-anak.

Metode kisah sangat baik digunakan untuk anak-anak karena anak-anak usia dini lebih tertarik dengan cerita-cerita. Anak lebih tergugah dan mendorong perasaannya untuk mengikuti pelajaran melalui cerita. Oleh karena itu cerita yang diberikan adalah cerita yang mengandung nilai moral, dan bersifat kebaikan sehingga dapat membentuk keimanan anak.

\footnotetext{
${ }^{5}$ Akbarizan, Op. cit, hlm. 155-156.
} 


\section{Pengalaman Shalat}

Shalat memiliki suatu posisi dan kedudukan khusus dalam pembinaan manusia, dan tidak ada suatu amal ibadah lain dalam agama yang dapat dibandingkan dengannya. Sekiranya kita hendak memilah-milah peringkat dan posisi masing-masing tuntutan agama, maka Shalat berada pada peringkat tertinggi. Shalat memiliki suatu nilai dan kedudukan yang amat tinggi yang tidak mampu dicapai oleh berbagai amal ibadah lainnya. ${ }^{6}$

Pengamalan merupakan suatu perbuatan melaksanakan untuk menunaikan tugas atau kewajiban. Kata Shalat dalam Islam pada dasarnya berakar dari kata "Shalat" yang berasal dari kata kerja "shalla, yushalla" kata Shalat menurut pengertian bahasa mengandung dua pengertian, yaitu berdoa dan bersalawat. Ini berarti bahwa ungkapan "saya Shalat" dapat berarti saya berdoa atau saya bersalawat. Berdoa yang dimaksud dalam pengertian ialah berdoa atau memohon hal-hal yang baik, kebaikan,kebajikan, nikmat, dan rezeki, sedangkan bersalawat berarti meminta keselamatan, kedamaian, keamanan, dan pelimpahan rahmat Allah swt. Shalat dalam pengertian tersebut adalah doa yang dilakukan untuk mendekatkan diri kepada Allah dan meminta pengampunan dari segala dosa, mensyukuri nikmat dan karunia yang diberikan Allah, untuk menolak kezaliman, dan untuk menegakkan suatu kewajiban ibadah dalam agama. ${ }^{7}$

Berdasarkan pernyataan tersebut dapat disimpulkan, pengamalan Shalat anak adalah suatu kegiatan atau rutinitas yang dilakukan anak untuk melakukan ibadah Shalat sesuai dengan syarat-syarat yang ditentukan dan tata cara pelaksanaan Shalat. Shalat mempunyai posisi tertinggi dalam ibadah lainnya dan Shalat merupakan aktivitas yang rutin dilaksanakan pada waktu-waktu tertentu, sehingga aktivitas Shalat pada anak harus diperhatikan apakah anak melaksanakannya atau tidak.

Orangtua yang salih adalah model terbaik untuk memberi pendidikan agama kepada anak-anak. Penanaman jiwa agama dimulai dari keluarga, semenjak anak kecil

\footnotetext{
${ }^{6}$ Musthafa Khalili, Berjumpa Allah Dalam Shalat, (Jakarta: Pustaka Zahra, 2004), hlm. 105.

${ }^{7}$ Ahmad Thib Raya dan Siti Musdah Mulia, Menyelami Seluk beluk Ibadah Dalam Islam, (Jakarta: Prenada Media, 2003), hlm.174.
} 
dengan cara membiasakan anak dengan tingkah laku yang baik. Pengasuhan yang diberikan dengan memperhatikan setiap tahap perkembangan anak.

Perkembangan anak usia dini masih banyak dipengaruhi oleh fantasi. Memasuki usia sekolah yaitu 6-12 tahun perkembangan agama anak sudah mengikuti realita yang diperolehnya dari pengajaran orang dewasa. Perubahan ini bisa dipengaruhi oleh perkembangan tingkatan usia atau bisa juga dengan pengaruh luar yang dialaminya. Pada usia ini keagamaan anak timbul berdasarkan dorongan emosional sehingga muncul konsep ketuhanan anak. Anak-anak lebih tertarik dan senang pada keagamaan yang mereka peroleh dari orang dewasa atau lingkungan mereka.

Dalam penelitian ini yang dimaksud anak adala anak dari keluarga orangtua tunggal. Orangtua tunggal mengasuh dan membesarkan anak-anak mereka sendiri tanpa bantuan pasangan, baik itu pihak suami maupun pihak istri. Orangtua tunggal memiliki kewajiban yang sangat besar dalam mengatur keluarganya. Keluarga orangtua tunggal memiliki permasalahan-permasalahan paling rumit dibandingkan keluarga yang memiliki ayah atau ibu. Orangtua tunggal dapat terjadi akibat kematian ataupun perceraian. $^{8}$

Orangtua tunggal maupun orangtua lengkap memiliki tanggung jawab dan peran yang sama dalam mendidik anak-anaknya. Memperlakukan anak sesuai dengan agama merupakan bagian dari ajaran Islam. Memahami anak berarti mengerti pola asuh yang baik, menjaga, melindungi, bertanggung jawab, memberikan contoh yang baik dan kasih sayang pada anaknya, mendidik dengan pendidikan agama.

Berdasarkan pernyataan tersebut dapat disimpulkan, pengamalan salat anak adalah suatu kegiatan atau rutinitas yang dilakukan anak untuk melakukan ibadah salat sesuai dengan syarat-syarat yang ditentukan dan tata cara pelaksanaan salat. Salat mempunyai posisi tertinggi dalam ibadah lainnya dan salat merupakan aktivitas yang rutin dilaksanakan pada waktu-waktu tertentu, sehingga aktivitas salat pada anak harus diperhatikan apakah anak melaksanakannya atau tidak.

${ }^{8}$ Zahrotul Layiliah, Perjuangan Hidup Orangtua tunggal, dalam Jurnal Sosiologi Islam, Volume 3, No. 1, April 2013. hlm. 90. 
Orangtua yang salih adalah model terbaik untuk memberi pendidikan agama kepada anak-anak. Penanaman jiwa agama dimulai dari keluarga, semenjak anak kecil dengan cara membiasakan anak dengan tingkah laku yang baik. Pengasuhan yang diberikan dengan memperhatikan setiap tahap perkembangan anak. Maka anak diajarkan untuk melaksanakan pribadi dan sosial, diantaranya adalah salat. ${ }^{9}$ Q.S Luqman ayat 17:

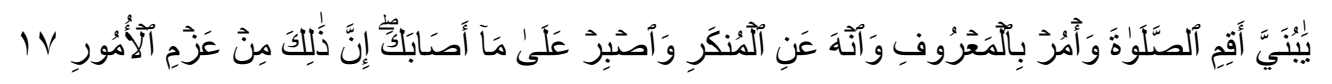

Artinya: "Hai anakku, dirikanlah salat dan suruhlah (manusia) mengerjakan yang baik dan cegahlah (mereka) dari perbuatan yang mungkar dan bersabarlah terhadap apa yang menimpa kamu. Sesungguhnya yang demikian itu termasuk hal-hal yang diwajibkan (oleh Allah)".

Berdasarkan firman Allah ini, jelaslah bahwa orangtua mempunyai kewajiban memberikan pendidikan agama pada anaknya, memperkenalkan keagungan Allah, memperkenalkan kewajiban agama termasuk salat. sebagaimana firman Allah diatas ketika Luqman memberi pendidikan agama pada anaknya yaitu menyuruh melaksanakan salat. pengamalan salat anak harus ditanamkan sejak usia dini. Masa anak merupakan priode perkembangan yang khusus karena memiliki kebutuhan psikologis, pendidikan, serta kondisi fisik yang khas dan berbeda dengan orang dewasa. ${ }^{10}$ Usia 6-12 tahun adalah masa anak sekolah. ${ }^{11}$

\section{METODOLOGI PENELITIAN}

Adapun jenis penelitian ini adalah penelitian tindakan partisipatori RAP (Riset Aksi Partisipatori). Penelitian tindakan partisipatori adalah penelitian yang dirancang untuk memberdayakan semua partisipan dalam suatu proses dengan tujuan untuk meningkatkan dan memperbaiki praktik yang diselenggarakan.

Berdasarkan tujuannya, penelitian ini termasuk penelitian eksploratif yaitu menemukan teori baru. Teori yang dimaksud adalah metode kisah dapat meningkatkan

\footnotetext{
${ }^{9}$ Rifa Hidayah, Op. Cit., hlm. 21-22.

${ }^{10}$ Wiwien Dinar Pratisi, Psikologi Anak, (Jakarta: Indeks, 2008), hlm. 7

${ }^{11}$ Rifa Hidayah, Psikologi Pengasuhan Anak, (Yogyakarta: UIN Malang Press, 2009), hlm. 6.
} 
pengamalan Shalat anak pada orangtua tunggal. Instrumen pengumpulan data menggunakan observasi dan dokumentasi.

\section{HASIL}

Hasil observasi yang dilakukan dengan tujuan untuk mengetahui pengamalan Shalat anak pada orangtua tunggal di Desa Manegen Kecamatan Padangsidimpuan Tenggara. Selama pelaksanaan kegiatan tindakan siklus I, peneliti bertindak sebagai observer yang mencatat kegiatan orangtua dan anak selama kegiatan berlangsung pada lembar observasi mendengarkan kisah dan lembar observasi membaca kisah.

Dalam kegiatan ini anak diarahkan untuk memperhatikan serta mendengarkan kisah dengan baik dan orangtua diarahkan membaca kisah dengan baik pula dan serius dengan didampingi oleh peneliti. Pada saat orangtua membaca kisah orangtua terlihat serius sedangkan anak kurang memperhatikan dan kurang antusias dalam mendengarkan kisah yang dibaca orangtua. Ditemukan pada lembar observasi hanya satu anak yang memperhatikan sedangkan yang lainnya diam tapi tidak memperhatikan orangtua yang membaca kisah.

Oservasi berikutnya pada lembar catatan Shalat anak yang diisi oleh orangtua tunggal, berdasarkan hasil observasi diketahui bahwa pengamalan Shalat anak setelah penerapan metode kisah belum mengalami peningkatan dan hasilnya tidak memuaskan. Pengamalan Shalat anak masih 1 atau 2 kali sehari semalam dengan rata-rata pengamalan Shalat anak perminggu 6.

Berdasarkan hasil observasi tersebut, peneliti melakukan analisis terhadap proses peningkatan pengamalan Shalat anak pada orangtua tunggal di Desa Manegen Kecamatan Padangsidimpuan Tenggara. Peneliti berpedoman pada hasil observasi peningkatan pengamalan Shalat anak pada orangtua tunggal melalui pedoman observasi aktivitas mendengarkan kisah, pedoman observasi aktivitas membaca kisah dan lembar catatan Shalat anak.

Adapun hasil analisis tersebut menunjukkan bahwa: Anak kurang memperhatikan dan tidak terfokus pada saat mendengarkan kisah. Aktivitas orangtua 
dalam membaca kisah pada pertemuan ini cukup serius dengan variasi suara saat membacakisah. Setelah observasi pengamalan Shalat anak dilakukan belum ada peningkatan pengamalan Shalat anak itu berarti peneliti perlu memperbaiki kekurangan tindakan pada tindakan selanjutnya.Oleh sebab itu peneliti membuat perencanaan untuk tindakan pada siklus berikutnya.

Pada siklus II yang dilakukan pada tanggal 04 maret 2018, peneliti tetap bertindak sebagai observer yang mengobservasi kegiatan orangtua dan anak saat kegiatan penerapan kisah berlangsung. Hasil observasi yang dilakukan dengan tujuan untuk mengetahui peningkatan pengamalan Shalat anak pada orangtua tunggal di Desa Manegen Kecamatan Padangsidimpuan Tenggara.

Pada kegiatan awal peneliti menginformasikan bahwa orangtua akan bercerita dan menyebutkan judul kisah yang akan dibaca. Pada kegiatan ini anak kurang antusias. Tahap berikutnya, ketika orangtua membaca kisah sambil menunjukkan gambar tanpa warna anak mulai memperhatikan. Dalam membaca kisah orangtua cukup serius dengan memvariasikan suara ketika membaca kisah. Aktivitas anak selama orangtua membaca kisah terlihat baik. Dengan adanya gambar yang ditunjukkan anak tertarik terhadap cerita dan memperhatikan orangtua yang membaca kisah, meskipun masih ada anak yang kurang memperhatikan.

Berdasarkan hasil observasi pada lembar catatan Shalat anak, anak melaksanakan Shalat 1, 2 kali sehari semalam sedangkan yang melaksanakan Shalat 3 kali sehari semalam hanya 2 orang anak dengan rata-rata pengamalan Shalat anak perminggu 7,5. Hal ini menunjukkan pengamalan Shalata nak belum meningkat dengan baik.

Berdasarkan pelaksanaan tindakan pada siklus II peneliti melakukan analisis terhadap proses peningkatan pengamalan Shalat anak pada orangtua tunggal di Desa Manegen Kecamatan Padangsidimpuan Tenggara. proses pelaksanaan tindakan pada siklus II belum cukup baik. Kelemahan yang ada pada siklus Ibelum teratasi dengan baik dan hasil pengamalan Shalat anak belum meningkat. 
Hasil penelitian pada siklus II terlihat bahwa sudah ada peningkatan perhatian anak dalam mendengarkan kisah yang disertai dengan gambar tanpa warna. Pengamalan Shalat anak jika dibandingkan dengan pengamalan Shalat anak pada tindakan siklus I belum meningkat dengan baik, itu berarti peneliti perlu memperbaiki kekurangan tindakan pada siklus selanjutnya.

Berdasarkan hasil observasi yang dilakukan pada siklus III, selama kegiatan berlangsung peneliti mengobservasi kegiatan orangtua dan anak pada lembar observasi mendengarkan kisah dan lembar observasi membaca kisah. Sebelum memulai kegiatan, peneliti mengarahkan orangtua supaya membaca kisah sambil menunjukkan gambar berwarna disertai dengan memainkan mimik wajah, bahasa tubuh serta variasi suara untuk lebih menekankan kisah yang yang dibaca dan anak diarahkakn untuk mendengarkan kisah dengan baik. Ketika diarahkan orangtua dan anak mendengarkan dengan baik.

Memasuki kegiatan tindakan, diketahui bahwa pada saat orangtua membaca kisah ternyata orangtua merasa canggung dan kurang bisa memainkan mimik wajah. Orangtua hanya bisa memainkan variasi suara dan bahasa tubuh saat membaca kisah. Itupun tidak semua orangtua bisa memainkan bahasa tubuh masih ada orangtua yang merasa canggung dan meskipun begitu orangtua tetap serius dalam membaca kisah.

Pada saat mendengarkan kisah, perhatian anak sudah mengalami peningkatan dan anak terlihat antusias dengan ditunjukkannya gambar berwarna, anak semakin tertarik dengan kisah yang dibacakan oleh orangtua ditambah dengan judul kisah “ Wajah Hitam Akibat Meninggalkan Shalat" yang membuat anak semakin tertarik. Begitu juga dengan pengamalan Shalat anak sudah ada peningkatan melalui kisah yang dibacakan dan bimbingan yang diberikan orangtua kepada anak. Hal ini dilihat berdasarkan lembar catatan Shalat anak dari yang melaksanakan Shalat 1,2, 3 dan 4 kali sehari semalam meskipun tidak semua anak melaksanakan Shalat 3, 4 kali sehari semalam. Adapun rata-rata pengamalan Shalat anak perminggu adalah 9,5.

Proses pelaksanaan tindakan pada siklus III sudah cukup baik. Hal ini ditunjukkan dengan pengamalan Shalat anak yang mengalami peningkatan. Adapun 
masih ditemukannya anak yang kurang memperhatikan dan belum mengalami peningkatan pengamalan Shalat tidak menjadi hambatan bagi peneliti dalam melaksanakan penelitian ini, karena kita tahu bahwa karakteristik, kemampuan dan daya tangkap anak itu beraneka ragam.

Peneliti dengan dibantu orangtua dan rekan peneliti lainnya telah melakukan penelitian yang bertujuan untuk meningkatkakn pengamalan Shalat anak pada orangtua tunggal di Desa Manegen Kecamatan Padangsidimpuan Tenggara.

Dari hasil penelitian siklus I belum ada peningkatan pengamalan Shalat anak. Jumlah ideal pengamalan Shalat anak perminggu perorang maupun perkelompok jika dibandingkan dengan hasil tindakan pengamalan Shalat anak perminggu perorang dan perkelompok masih jauh dari jumlah ideal. Begitu juga dengan siklus II, pengamalan Shalat anak belum meningkat dengan baik dan masih jauh dari jumlah ideal. Dilihat dari rata-rata pengamalan Shalat anak siklus I terhadap siklus II pengamalan Shalat anak juga belum meningkat dengan baik, yaitu siklus I diperoleh rata-rata 6 menjadi 7.5 pada siklus II.

Berdasarkan hasil penelitian pada siklus III pengamalan Shalat anak perminggu perorang sudah hampir mencapai setengah dari jumlah ideal yaitu diperoleh jumlah 15 dan jumlah pengamalan Shalat anak perminggu perkelompok masih jauh dari jumlah ideal. Hasil tindakan rata-rata pengamalan Shalat anak pada siklus I diperoleh 6 dan siklus II diperoleh rata-rata 7.5. Pada siklus III, rata-rata pngamalan Shalat anak diperoleh 9.5. pengamalan Shalat anak jika dibandingkan dari rata-rata siklus I, siklus II dan siklus III, maka pada siklus III pengamalan Shalat anak meningkat.

Berdasarkan data yang ada, maka hasil penelitian dari observasi yang dilakukan sejalan dengan teori yang dikemukakan pada bab II. Hasil penelitian tidak menyanggah teori yang ada sebelumnya. Hal ini terbukti dengan adanya peningkatan pengamalan Shalat anak setelah dilakukan kegiatan penerapan metode kisah. Hasil penelitian ini adalah metode kisah dapat meningkatkan pengamalan Shalat anak pada orangtua tunggal. 
Metode kisah dapat diterima dalam peningkatan pengamalan Shalat anak karena metode kisah dikenal sebagai metode yang mashur, sebab kisah dapat menyentuh jiwa dan mengarahkan emosi jika didasari oleh ketulusan hati yang mendalam. Kisah memiliki daya tarik yang dapat menyentuh perasaan pembaca atau pendengar. Kisah juga mempunyai pengaruh dan bimbingan untuk mengadakan perubahan dan pengarahan pada orang yang mendengar kisah tersebut.

Metode kisah ini efektif digunakan terlebih lagi bila sasarannya adalah anak didik yang masih dalam perkembangan fantastik. Jika dilihat dari segi usia, usia 6 sampai 12 tahun sangat memerlukan bimbingan dari orangtua, termasuk bimbingan keagamaan. Maka metode kisah cocok digunakan untuk membimbing ank-anak bila kisah yang digunakan adalah kisah yang mengandung kebaikan.

Dari hasil penelitian yang telah dilakukan di Desa Manegen Kecamatan Padangsidimpuan Tenggara, diperoleh hasil bahwa penerapan metode kisah dapat meningkatkan pengamalan Shalat anak pada orangtua tunggal di Desa Manegen Kecamatan Padangsidimpuan Tenggara seperti data yang diperoleh pada tindakan siklus I, siklus II dan siklus III dari hasil catatan pngamalan Shalat anak, dengan nilai rata-rata yang diperoleh yaitu:

\begin{tabular}{|c|c|c|c|c|c|}
\hline \multirow{2}{*}{ Siklus } & \multicolumn{5}{|c|}{ Pengamalan Shalat Anak } \\
\cline { 2 - 6 } & $\begin{array}{c}\text { Ideal/minggu } \\
\text { /orang }\end{array}$ & $\begin{array}{c}\text { Ideal/minggu } \\
\text { /kelompok }\end{array}$ & $\begin{array}{c}\text { Hasil/minggu } \\
\text { /orang }\end{array}$ & $\begin{array}{c}\text { Hasil/minggu } \\
\text { /kelompok }\end{array}$ & Rata-rata \\
\hline I & 35 & 210 & 7 & 36 & 6 \\
\hline II & 35 & 210 & 10 & 45 & 7.5 \\
\hline III & 35 & 210 & 15 & 57 & 9.5 \\
\hline
\end{tabular}

\section{E. DAFTAR PUSTAKA}

Ahmad Thib Raya \& Siti Musdah Mulia, Menyelami Seluk Beluk Ibadah Dalam Islam, Jakarta: Prenada Media, 2003.

Akbarizan, Pendidikan Berbasis Akhlak, Pekan Baru: Suska Press, 2008.

Armai Arief, Penganntar Ilmu Dan Metodologi Pendidikan Islam, Jakarta: Ciputat Pers, 2002. 
Muhammad Abdul Qadir Ahmad, Metodologi Pengajaran Agama Islam, Jakarta: Rineka Cipta, 2008.

Musthafa Khalili, Berjumpa Allah Dalam Salat, Jakarta: Pustaka Zahra, 2004.

Rifa Hidayah, Psokologi Pengasuhan Anak, Yogyakarta: UIN Malang Press, 2009.

Wiwien Dinar Pratisi, Psikologi Anak Usia Dini, Jakarta: Indeks, 2008

Zahrotul Layiliah, Perjuangan Hidup Orangtua Tunggal, dalam Jurnal Sosiologi 